\title{
Dois «sonhadores práticos» no campo das reformas sociais da Medicina: Tomás Judym e José Tomás de Sousa Martins
}

\author{
Two "practical dreamers» in the field of medical social reforms: \\ Tomás Judym and José Tomás de Sousa Martins
}

Anna KalewsKa ${ }^{1}$

Resumo: Depois do romantismo, o passado mítico-lendário foi questionado pela Ciência positivista e pelo espírito de reformas sociais, ganhando novos contornos literários nas obras sensíveis aos problemas da sociedade, patriótica e politicamente empenhadas. A obra de Stefan Żeromski (1864-1925), que, nas primeiras décadas do século $\mathrm{xx}$, era considerado o maior romancista polaco, fez com que a função puramente estética da Literatura perdesse terreno, instigando o lado emocional e a consciência social dos seus leitores, a sua compaixão e vontade de agir. 0 protagonista do romance Ludzie bezdomni (1900) (Os homens sem teto), doutor Tomás (Tomasz) Judym, é um self-made man que, assumindo a responsabilidade pela miséria das massas do proletariado (primeiro, em Paris, depois, em Varsóvia, em Cisy e na Silésia), renuncia à sua própria felicidade e ao amor de Joaninha, e dedica a sua vida de médico aos pobres e à luta contra a injustiça social. 0 inconformismo e o empenhamento do doutor Judym como o primeiro «sonhador prático» da causa social tornaram-se proverbiais em polaco, conotando a atitude romântica livre da vontade de lucro financeiro na época do progresso desenfreado do capitalismo.

José Tomás de Sousa Martins (1843-1897) foi um «sonhador prático» real, uma figura ímpar da Ciência portuguesa, médico e professor catedrático na Escola Médico-Cirúrgica de Lis- boa, empenhado gratuitamente no combate à tuberculose. Em 1910, Jaime Cortesão traçou o perfil de Sousa Martins, sublinhando que, em Filosofia, foi positivista, materialista e determinista-fatalista, indo muito além da superstição científica que levava os que prezavam a Ciência para além dos limites do razoável, acrescentemos que também para além do limite da humanidade. Na verdade, Sousa Martins era um pasteuriano convicto e partilhou as ideias científicas do mestre francês. Para Sousa Martins, Pasteur era um dos santos a adorar na vasta religião da Ciência.

O doutor Tomás Judym e Sousa Martins entraram, respetivamente, na Literatura polaca e na História da Saúde Pública em Portugal como «santos laicos», figuras paradigmáticas da ação no campo das reformas sociais, médicos ao serviço do Homem, que não viam na religião o caminho para a sua salvação, mas antes na Ciência. E, também por isso, as figuras dos dois «sonhadores práticos» se tornam ainda mais fascinantes e recomendáveis à apresentação no tempo do debate sobre o espírito das reformas e a (re)construção da modernidade.

Palavras-chaves: Romantismo; positivismo; cientificidade; religião; superstição.

${ }^{1}$ Instituto de Estudos Ibéricos e Ibero-Americanos da Universidade de Varsóvia. a.kalewska@uw.edu.pl. 
Abstract: After Romanticism, the mythical-legendary past was questioned by Positivist Science and the spirit of social reforms, gaining new literary contours in patriotically and politically committed works that were sensitive to the problems of society. The work of Stefan Żeromski (1864-1925), who in the first decades of the twentieth century was considered the greatest Polish novelist, caused the purely aesthetic function of Literature to lose ground, instigating the emotional side and social consciousness of its readers, their compassion and willingness to act. The protagonist of the novel Ludzie bezdomni (1900) (Homeless Men), Doctor Tomás (Tomasz) Judym, is a self-made man who, assuming responsibility for the misery of the masses of the proletariat (first in Paris, then in Warsaw, in Cisy and Silesia), renounces his own happiness and the love of Joaninha, and dedicates his life as a doctor to the poor and to the fight against social injustice. The nonconformity and commitment of Dr. Judym as the first «practical dreamer» of the social cause became proverbial in Polish, characterizing the romantic attitude free of financial gain in the time of capitalism's unbridled progress.

José Tomás de Sousa Martins (1843-1897) was a real "practical dreamer», an unparalleled fige ure in Portuguese Science, a physician and professor at the Medical-Surgical School of Lisbon, who fought tuberculosis free of charge. In 1910, Jaime Cortesão outlined the profile of Sousa Martins, emphasizing that in Philosophy he was positivist, materialist and determinist-fatalist, going far beyond the scientific superstition that took those who prized Science beyond the limits of reasonable, beyond the limit of mankind. In fact, Sousa Martins was a committed pasteurian and shared the scientific ideas of the French master. For Sousa Martins, Pasteur was one of the saints to be worshiped in the vast religion of Science.

Dr. Tomás Judym and Sousa Martins entered, respectively, in Polish Literature and in the History of Public Health in Portugal as «lay saints», paradigmatic figures of action in the field of social reforms, physicians at the service of Man, who did not see in religion the way to their salvation, but rather in Science. And so the figures of the two «practical dreamers» become even more fascinating and recommendable to the presentation of the debate over the spirit of reforms and the (re)construction of modernity.

Keywords: Romanticism; positivism; scientificity; religion; superstition. 
À memória de meu pai e minha avó.

O homem é criado para a felicidade! O sofrimento precisa de ser combatido como o tifo ou a varíola. (Żeromski, 2016)

\section{Stefan Żeromski - o «pai» espiri- tual do doutor Judym como o escritor polaco do pós-independência e os percursos da construção da identi- \\ dade moderna e nacional}

Depois do romantismo, o passado mítico-lendário foi questionado pela Ciência positivista e pelo espírito de reformas sociais, ganhando novos contornos literários nas obras sensíveis aos problemas da sociedade, patriótica e politicamente empenhadas. A obra de Stefan Żeromski (1864-1925), que, nas primeiras décadas do século $x x$, era considerado o maior romancista polaco, fez com que a função puramente estética da Literatura perdesse terreno, instigando o lado emocional e a consciência social dos seus leitores, a sua compaixão e vontade de agir.

Stefan Żeromski, que utilizou o pseudónimo Maurycy Zych, era órfão de mãe e pai, tísico, pobre, autodidata, escritor, professor particular e pintor de retratos femininos em efígie de mãe. Viveu em Varsóvia no período entre as guerras, ali morrendo em 1925.

Eis alguns termos e dados, datas e factos relacionados com o autor:
- Função/papel: a consciência da nação polaca, a consciência da Literatura polaca;

- «Żeromszczyzna»: a estética de Żeromski, baseada na exuberância de metáforas, epítetos, comparações e arrebatamentos emotivos, assim como na postura idealística quanto à possibilidade das reformas sociais operadas pela intelligentsia em prol do proletariado urbano e rural;

- Simpatizante do socialismo (e da Revolução de 1905), cooperativismo e sindicalismo;

- Maçon (?);

- Mestres: Georges Sorel e Édouard Dufour;

- Viagens: 1892 - Zurique, Viena, Praga e Cracóvia; 1909-1912 - Paris;

- Esposa: Oktawia Żeromska, Oktawia z Radziwiłłów Rodkiewiczowa-Żeromska, (4 de dezembro de 1862-10 de julho de 1928), protótipo de Joanna Podborska, namorada do doutor Tomás Judym em Ludzie bezdomni. Filho: Adam Żeromski (1899-1918). Adam Żeromski morreu de tuberculose a 31 de julho de 1918. S. Ż. dedicou-lhe um texto de temática sociopolítica: Początek świata pracy (1918) (O início do mundo laboral);

- Amante: Anna Zawadzka (1888-1983); filha: Monika Żeromska (1913-2001);

- Sepultado no cemitério evangélico-reformista em Varsóvia; 
- Avaliação final pela crítica literária: «Żeromski was, first of all, a public figure of great stature; this, together with his feeling for the unexplored resources of the Polish language - and his vocabulary is of a stupendous richness - secures him a place apart in Polish literature.» (Milosz, 1984: 369).

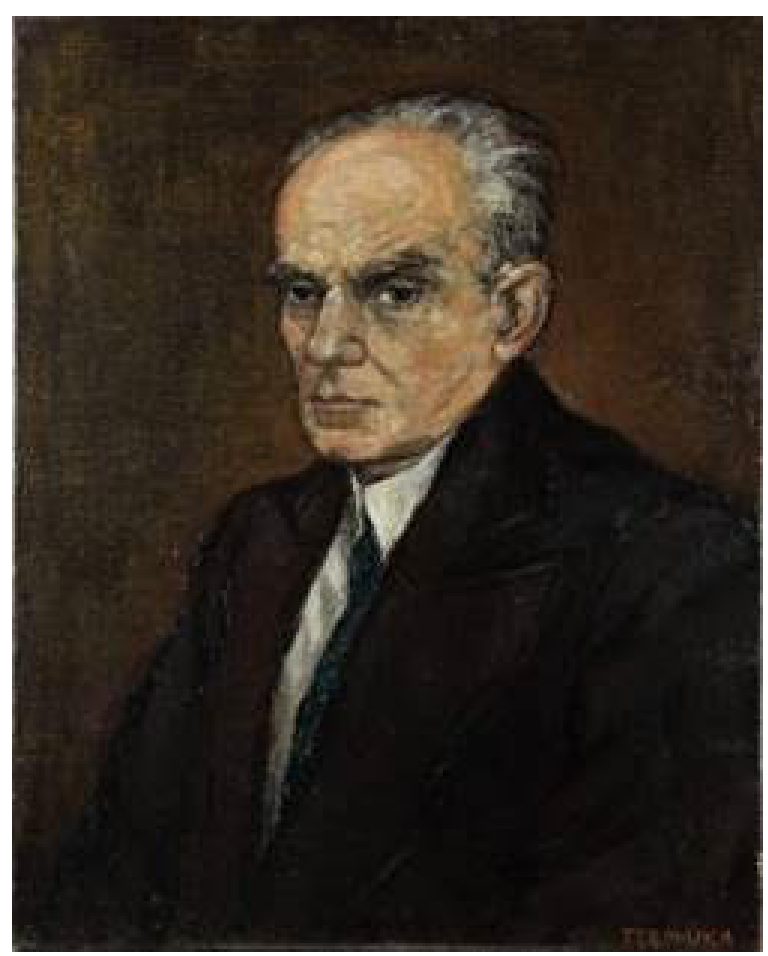

Foto 1 - Stefan Żeromski (1964-1925). Retrato no Museu Nacional de Kielce, Polónia. (Domínio público)

\section{Os romances mais conhecidos de Żeromski} são os seguintes: Siłaczka (1895) (Uma mulher forte), um romance sobre a heroica professora primária Stasia Bozowska, que morreu de tifo após ter ministrado a pedagogia de patriotismo e perseverança no meio ambiente provinciano e ingrato de Obrzydłówek; Syzyfowe prace (1898) (Os trabalhos de Sísifo) ${ }^{2}$; Ludzie

\footnotetext{
${ }^{2}$ «O romance Os trabalhos de Sísifo, 1898, mostra como é cor-
} rompido o sistema de educação, como são inadequados os bezdomni (1900) (Os homens sem teto), cujo protagonista - também em foco na nossa análise -, doutor Tomás Judym, renuncia à felicidade pessoal para se dedicar ao exercício da Medicina em prol dos pobres33; Popioły (1904) (As cinzas) ${ }^{4}$; Dzieje grzechu (1908) (O caminho da culpa) ${ }^{5}$; Wierna Rzeka (1912) (O rio fiel), o romance mais lido e conhecido de Żeromski; Przedwiośnie (1924) (Antes da primavera);

programas de ensino e como funciona o mecanismo de russificação [...]. Toda essa problemática está inserida na história de um adolescente, filho de trabalhador rural, sua iniciação na vida adulta e sua resistência ao plano de russificação da escola» (Siewierski, 2000: 135).

${ }^{3}$ «I am responsible for everything here! I am responsible before my spirit which cries out within me: I protest! I, a doctor, will not do it, who will? I have received everything that I need. I must give back what I have taken. That damned debt! ... I can have no father, no mother, no wife, not a single thing that I might press to my heart with love, as long as those nightmares [Warsaw slums and workers' towns in the mining district of Silesia] exist. I must renounce happiness. I must be alone» (Milosz, 1984: 366).

${ }^{4}$ «O romance histórico As Cinzas (1904) é um amplo panorama da vida dos poloneses na época das guerras napoleônicas. Os personagens principais lutam em campos de batalha de toda Europa e a narração apresenta tanto as suas experiências militares quanto os seus estados psicológicos; tanto relatos épicos das batalhas, quanto descrições líricas da natureza. 0 romance mostra o heroísmo e o lado trágico da guerra; a compaixão para com as vítimas é mais forte do que o fascínio pelos feitos heróicos» (Siewierski, 2000: 135).

5 Em 1975, Walerian Borowczyk realizou um melodrama sobre a força destruidora do amor entre uma jovem muLher (Eva, interpretada por Ewa Długołęcka) e um homem casado. A película foi nomeada para a Palma de Ouro no Festival de Cannes.

${ }^{6}$ «Em seu último romance, Antes da Primavera (1924), Żeromski faz uma diagnose da situação da Polônia depois da libertação [1918]. A euforia não apaga os lados sombrios e as antinomias da vida social. Um dos problemas cruciais, a revolução social, é visto pelo prisma da Revolução Russa, vivida pelo protagonista, quando como adolescente acompanhava o seu pai, engenheiro que trabalhava nos campos de petróleo em Baku» (Siewierski, 2000: 135). 
Uciekła mi przepióreczka (1924) (Fugiu-me uma pequena codorniz); e Wiatr od morza (1922) (O vento do mar). Seria de lembrar que, em 1924, o romance épico Chłopi (Os camponeses), de Władysław Reymont (1867-1925) - rival de Żeromski -, ganhou o Prémio Nobel da Literatura, facto meritório que não tira o justo renome do autor aqui representado ${ }^{7}$ como um dos maiores escritores polacos da primeira metade do século xx, imbuído do espírito das reformas sociais, políticas e culturais no importante período da Primeira República da Polónia, instaurada em 1918, após a longa época das «partilhas» do país entre as superpotências vizinhas (1795-1918).

Como bem nos lembra Adam Zamoyski, na História da Polónia, na época da reconstrução da nação polaca, as Artes (inclusive a Literatura) foram profundamente marcadas pela sua sujeição às causas nacionais ou ao progresso social. Os escritores concentraram-se em temas que suscitavam questões sociais e nacionais. Este espírito de reformas tardo-positivistas distinguiu-os não só dos historicistas românticos, mas também daqueles artistas que seguiram as correntes modernistas da Arte

\footnotetext{
7 «During the first quarter of the $\left[\mathrm{xx}^{\text {th }}\right]$ century, nobody, not even his enemies, questioned Żeromski's position as the most important Polish fiction writer. He was called an insatiable heart, the conscience of Polish literature, and the awarding of the Nobel Prize to Reymont for his Peasants [Chłopi] provoked some indignation among the Poles. It was felt Żeromski should have received it. His extraordinary gift for compassion, his open-mindedness, and the dramatic plots of his books account for that worship» (Milosz, 1984: 369).
}

europeia e abraçaram tendências como o futurismo, o dadaísmo e o impressionismo.

Passamos a citar o historiador polaco supramencionado, para frisar o nosso apelo aos «leitores pensantes», sensíveis ao espírito das reformas e à construção da modernidade concebidos, lato sensu, dentro dos Estudos Culturais $^{8}$-, tanto na Polónia como em Portugal:

Todas as gerações contribuíram com escritores novos, alguns dos quais, como o novelista Stefan Żeromski (1864-1927), mantiveram vivo e elevaram a novos patamares o debate político, perscrutando todos os aspectos da vida e escrutinando tudo, desde o passado histórico até às instituições sociais, às iniciativas filantrópicas e ao cooperativismo. Władysław Reymont (1867-1925), filho de um organista de aldeia, foi sucessivamente aprendiz de alfaiate, monge, escriturário e várias outras coisas até se tornar escritor e ganhar o Prémio Nobel. A sua Ziemia Obiecana (Terra Prometida), 1899, uma novela ao estilo de Zola cujo enredo decorre no centro industrial de Łódź, então em grande expansão, transmite o veredicto do autor sobre a fé positivista na regeneração pelo progresso material. «As aldeias foram abandonadas, as florestas derrubadas, a terra espoliada dos seus tesouros, os rios secados, nasceram as pessoas - tudo por aquela Terra Prometida, aquele pólipo que os

\footnotetext{
${ }^{8}$ «De uma forma geral, chamamos Estudos Culturais à disciplina que se ocupa do estudo dos diferentes aspectos da cultura, envolvendo, por exemplo, outras disciplinas como a história, a filosofia, a sociologia, a etnografia, a teoria da literatura, etc.» (Ceia, s. d.). Perfilhamos a postura metodológica fixada no espírito dos Estudos Culturais e das reformas.
} 
sugava [...], dando em troca milhões inúteis a uma meia dúzia e fome». A estes autores, seguiram-se vagas de escritores que aderiram a novos cânones literários e estilísticos. Mas independentemente das suas áreas de proveniência, todos contribuíram para um processo sustentado de construção nacional, nem que fosse por aglutinarem e alargarem um corpo de leitores pensantes que englobava não apenas os impérios russo, alemão e austro-húngaro, mas também a Europa Ocidental, os Estados Unidos e a América do Sul. (Zamoyski, 2010: 261)

Os escritores na Polónia, no limiar da independência e da recriação da República polaca, não se podiam dar ao luxo de perder demasiado tempo com glórias passadas ou tendências novas e sofisticadas, dado que a questão da forma ideológica do mundo que pretendiam criar começava a tornar-se verdadeiramente urgente. A nação polaca fora aberta a todas as nacionalidades, mas, quando a Polónia foi ressuscitada como Estado-nação, em 1918, apenas se pôde basear nas tradições linguísticas, culturais e religiosas do grupo dominante, isto é, da intelligentsia oriunda ora da grande e pequena nobreza ora, em casos muito raros, da classe média constituída em virtude do trabalho representado pelos membros do proletariado. 0 caso do doutor Tomás Judym é paradigmático desta segunda possibilidade, desenhada com cores realistas, modernistas e simbólicas no romance modernista de Stefan Żeromski intitulado Ludzie bezdomni (Os homens sem teto), publicado em 1900, na charneira dos séculos XIX e Xx (escrito em 1899 em Zakopane).

Ao escrever o seu romance, Żeromski valeu-se da técnica realista e naturalista, criando uma obra social e de costumes, que continha uma vasta apresentação de vários grupos e classes sociais. 0 recurso à técnica naturalista é visível nas descrições dos bairros pobres de Paris e Varsóvia, das fábricas da Silésia, das casas de albergue para os sem-abrigo e nos discursos sobre as vicissitudes passadas e futuras dos protagonistas. Essas descrições caracterizam-se pelo enfoque interno detalhado e pelo tratamento cuidadoso de um pormenor, não temendo a drasticidade naturalista (quadros de pobreza, abandono e doença). 0 cuidado da descrição realista, a verosimilhança e a minuciosidade nas referências espácio-temporais são típicos do método realista, assim como a motivação das ações dos protagonistas, resultando do seu estatuto social. Criando o mundo apresentado no romance, o autor faz justo uso da técnica do contraste, pintando em cores escuras a penúria do proletariado (urbano e rural) e em cores mais claras, com laivos de simbolismo um tanto eçiano (hipótese de interpretação nossa), a vida dos representantes da alta burguesia, desprovida dos valores patrióticos, tendendo à França ou à Alemanha. Os monólogos interiores dos protagonistas, 0 diário de Joaninha, os pensamentos internos do doutor Judym servem para uma melhor caracterização das personagens, incutem-lhes uma maior probabilidade. 
Sobre o romance em foco, Ludzie bezdomni (Os homens sem teto), a sua característica básica relacionada com o realismo-naturalismo e a possível influência de escritores russos do século XIX (Fiodor Dostoevskij, Mikhail Lermontov ${ }^{9}$, Lev Tolstoi, Nikolai Gogol e Ivan Turgieniv), Czesław Miłosz alvitra o seguinte:

Homeless People is a cruel novel which spares no image of abjection or misery. For this reason, and also because of his naturalistic leaning is his short stories, Żeromski was often attacked as a sadomasochist, and, in a much graver reproach, as contaminated by Russian prose writers. (Milosz, 1984: 367)

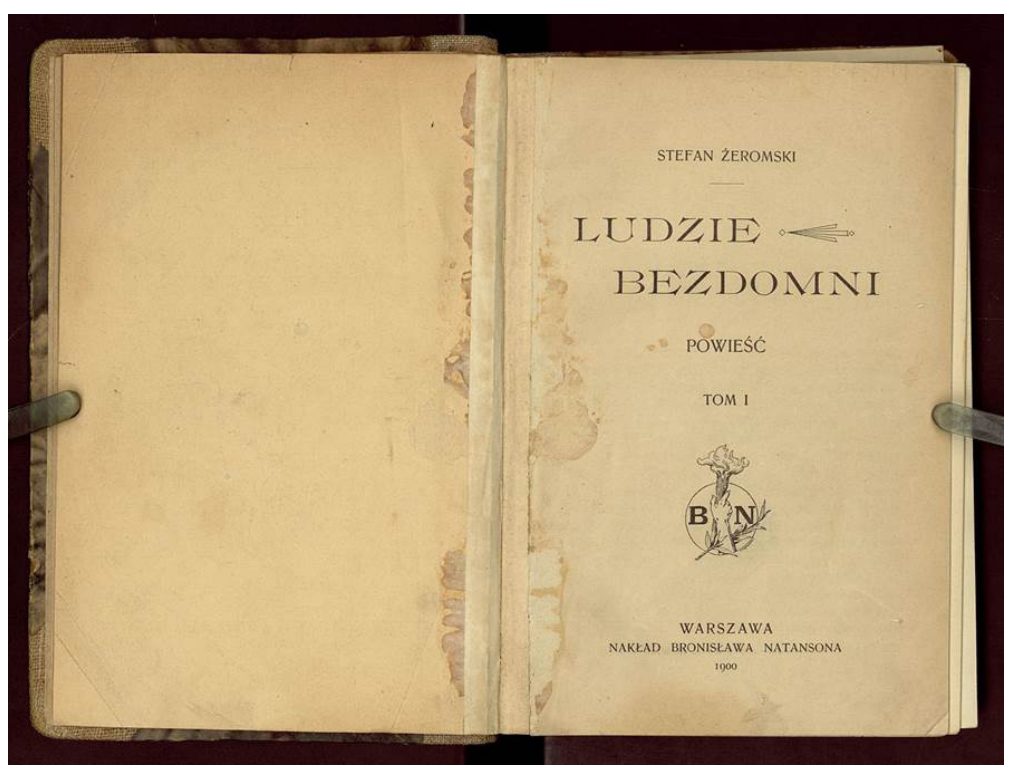

Foto 2 - Stefan Żeromski, Ludzie bezdomni (Os homens sem teto). Frontispício, chez Bronisław Natanson, Varsóvia, 1900. (Domínio público)

As críticas à obra de Żeromski, mencionadas por Czesław Miłosz, não tiram o justo mérito à

\footnotetext{
${ }^{9}$ Em 1882, Stefan Żeromski estreou-se com uma tradução de um poema de Mikhail Lermontov, publicada no n. 27 do Tygodnik Mód i Powieści (O Semanário das Modas e Romances).
}

profissão de médico, representada tanto pelo protagonista do romance Ludzie bezdomni (Os homens sem teto) como por José Tomás de Sousa Martins (1843-1897), o médico que passou para a História de Portugal como o «santo leigo» e continua a ser venerado até hoje, integrando-se na religião popular e na História da Cultura e Sociedade. O que é vital, porém, é o facto de o espírito das reformas associado ao exercício da Medicina transformar os nossos protagonistas - o ficcional, inventado por Stefan Żeromski, e o factual, representado por Sousa Martins - em símbolos vivos da Ciência e Filosofia positivista, levando a superstição, o ódio de classe e a desigualdade social para além dos limites do razoável, du côté de chez Louis Pasteur, Georges Sorel, Édouard Dufour e Edward Abramowski (1868-1918) - um filósofo, um psicólogo e um anarquista polaco, teórico do cooperativismo, amigo e gémeo espiritual do escritor polaco em causa.

\section{0 doutor Tomás Judym ou «o pinheiro dilacerado» entre 0 dever e o amor}

O protagonista do romance Ludzie bezdomni (1900) (Os homens sem teto), doutor Tomás (Tomasz) Judym ${ }^{10}$, é um médico de tipo self-

\footnotetext{
10 Há duas hipóteses sobre a personagem-mestre e base histórica do doutor Tomás Judym. A primeira (de Stanisław Adamczewski (1930)) reza que o protótipo do doutor Judym teria sido o doutor Tomasz Janiszewski, especializado em pneumologia, educado na Grã-Bretanha, Irlanda e Áustria,
} 
-made man que, assumindo a responsabilidade pela miséria das massas do proletariado, primeiro, em Paris, depois, em Varsóvia, em Cisy (o sanatório imaginado que tinha como seu «original» a estação balneária conhecida na Polónia como Nałęczów) e na Baixa Silésia, renuncia à sua própria felicidade e ao amor de Joaninha, e dedica a sua vida de médico aos pobres e à luta contra a injustiça social. 0 inconformismo e o empenhamento do doutor Judym como o primeiro «sonhador prático» da causa social tornaram-se proverbiais em polaco, conotando a atitude romântica livre da vontade de lucro financeiro na época do progresso desenfreado do capitalismo. Lembremos a postura idealista do doutor Judym, citada por Czesław Miłosz:

In the final chapter of the novel, he rejects the love of a woman (whose love he returns), as in his battle for social justice he would be weakened by founding and caring for a family. Such an idealistically minded figure account

radicado em Zakopane (no sul da Polónia), onde podia ter conhecido Stefan Żeromski e travado com o escritor longas conversas sobre o progresso da Medicina, a divulgação da higiene entre as massas populares, a proteção da saúde e a melhoria do estado social dos menos prevenidos. A segunda hipótese (de Ludwik Krzywicki, famoso sociólogo polaco) sugere, como modelo do doutor Judym, o doutor Józef Zieliński, que tinha concluído um curso de Medicina em Paris, onde se empenhou na ação social entre os operários polacos, fundado a sociedade Solidariedade, juntamente com a biblioteca contígua, e organizado a Universidade Popular Polaca. Contudo, ao contrário do doutor Judym, Józef Zieliński casou-se. A semelhança dos protagonistas e deuteragonistas dos romances de Żeromski com as personagens autênticas observou-a Jerzy Kądziela (1976). for the term Żeromszczyzna, or, the quality of being like Żeromski's heroes; the word used ironically by the novelist's adversaries. Those adversaries were mostly on the political Right. All those who rallied to the Polish Socialist Party or who were sympathizers of it, like Żeromski himself, did not seem to mind this rather sentimental approach to social problems. (Milosz, 1984: 367)

Żeromski descreve os sucessos da vida de Tomás Judym, a sua atividade profissional e social e o amor à jovem professora, Joanna Podborska. O protagonista encarna os ideais do sacrifício profissional para a justa causa do exercício da Medicina, deixando, porém, alguma dúvida quanto à pertinência das suas escolhas no campo da vida pessoal, íntima e lírica. O reformismo de Żeromski, segundo Czesław Miłosz, tinha, pois, contornos imprecisos, carecendo de uma ideia geral das reformas sociais do seu tempo ${ }^{11}$. Face ao que ficou dito, algumas realidades diegéticas, assim como as reformas sociais e as posturas ideológicas propostas pelo doutor Tomás Judym em Ludzie bezdomni - quem sabe, a atitude do próprio autor - merecem uma listagem bem ponderada:

- Em Varsóvia, chez le monsieur doutor Czernisz, Judym apresenta uma palestra, «Algumas observações ou uma palavra sobre a higiene», falando sobre as condições de vida miseráveis

11 «He merely presented the sad social reality without proposing solutions (in truth, he had never had solutions for the pressing issues of the day)» (Milosz, 1984: 369). 
do proletariado em Paris e na casa de albergue de pobres Château-Rouge e tratando também da vida dos pobres nos bairros sociais de Varsóvia, advogando a necessidade de melhorar as condições de higiene e os serviços médicos gratuitos para os pobres; o doutor Judym foi criticado pelo establishment médico pelos «arrebatamentos altruístas»;

- Nutre a crença no progresso desenfreado da sua disciplina quanto às reformas sociais; está convencido de que «a Medicina vai traçar caminhos para as massas do povo, vai levantar e regenerar o mundo» (Żeromski, 2016: 143);

- Em Cisy (Nałęczów), Judym, como o médico do sanatório, «aqui vai semear, vai trabalhar pela multidão de pessoas, devolvendo ao mundo tudo o que tinha dele recebido. Não vai poupar os braços nem o suor! Que o saibam como pode ser grato um [médico] da arraia-miúda a quem concederão uma parte dos seus direitos para a acção [em prol da meLhoria da condição social do povo]», pretende «pôr a alma no trabalho duro de médico no hospital» (Żeromski, 2016: 143);

- Visita os doentes nas aldeias, sem cobrar dinheiro; «quanto mais trabalhava, maior poder em si sentia, o de um arrebatamento e paixão que crescia e endurecia de faina como um músculo» (Żeromski, 2016: 144);
- É um «sonhador prático» ${ }^{12}$, agindo por conta própria, trabalhando arduamente na Polónia russificada (o irmão Víctor emigrou para os EUA para viver melhor do que em Varsóvia);

- Protesta contra o esgotamento das águas poluídas na lagoa local, as quais os camponeses bebiam; «contra o que se faz aqui eu protesto solenemente!» (Żeromski, 2016:181);

- Resultado: dissolução do contrato, procura de um novo emprego, partida para a Silésia;

- Reformas ou sensibilidade social, em laivos de simbolismo, naturalismo e expressionismo;

- T.Judym nutre alguma inveja dos ricos, mas, mesmo assim, implementa sempre os ideais do trabalho positivista em prol do povo;

- Após ter deixado o balneário Cisy, o doutor Judy, através do engenheiro Korzecki (protótipo: filósofo e ativista social Edward Abramowski), toma conhecimento de um emprego na mina de carvão Sixto (Sykstus) na província da Silésia (em Sosnowiec/Sosnowitz);

- Como médico de fábrica, Judym trata os doentes pobres, compartilhando a sorte destes segundo o princípio do supremo bem social, acreditando que «a felicidade de um

\footnotetext{
${ }^{12}$ Assim como M. Les, com quem se correspondia quase diariamente. No nosso entender, tanto Judym como José Tomás de Sousa Martins foram os «sonhadores práticos» (a expressão é de Żeromski).
} 
indivíduo tem que ser subordinada à felicidade comum» ${ }^{13}$;

- Encontro com Joanna Podborska, que quer ajudá-lo no trabalho, imaginando a vida laboriosa e feliz, modesta e socialmente proveitosa de um casal de médico e professora primária ${ }^{14}$;

- O doutor Judym, renunciando ao amor e ao casamento com Joanna Podborska, argumenta que tem que «devolver tudo o que tinha recebido. Esta dívida maldita... Não posso ter nem pai, nem mãe, nem mulher, nem uma coisa qualquer que aperte com o amor ao coração, antes que da superfície da terra desapareçam esses ignóbeis fantasmas. Tenho que renunciar à felicidade. Tenho que estar só, único. Para que ninguém esteja junto de mim, ninguém me prenda!» ${ }^{15}$;

13 «Szczęście jednostki musi być podporządkowane dobru ogółu» (Żeromski, 2016: 210) (a tradução para português no texto principal é da autora). Nesta asserção, reconhecemos o legado do romantismo na ação positivista de Tomás Judym, assim como a postura ideológica de Stefan Żeromski, vinculada à época anterior e à prosa do século XIX.

14 «Ani się obejrzysz, kiedy nasze mieszkanie pełne będzie sprzętów prostych jak u najuboższych ludzi, ale za to pięknych jak u nikogo. My tu stworzymy źródło poczucia piękna, nowego piękna, sztuki jeszcze nie znanej, która obok nas śpi jak zaczarowana królewna. Będą to stołki sosnowe, ławy, stoły. Będą je okrywały proste kilimy ...» (Żeromski, 2016: 231).

15 «Muszę oddać, com wziąt. Ten dług przeklęty... Nie mogę mieć ano ojca, ani matki, ani żony, ani jednej rzeczy, którą bym przycisnął do serca z miłością, dopóki z oblicza ziemi nie znikną te podłe zmory. Muszę wyrzec się szczęścia. Muszę być sam jeden. Żeby obok mnie nikt nie był, nikt mię nie trzymał!» (Żeromski, 2016: 233).
- Renunciando ao amor, Tomás Judym fica só que nem um pinheiro rasgado ${ }^{16}$, tendo em vista os seus objetivos: pagar a «dívida maldita» (a alegada culpa de ter ingressado na classe da intelligentsia) e ajudar os doentes, pobres e desprevenidos, tornando-se «um homem sem teto» e o padrão do empenhamento positivista e total na causa das reformas sociais;

- A metáfora dos «homens sem teto» designa o médico e a professora, ambos dedicados ao «trabalho de base» (praca $u$ podstaw) positivista, sem hipótese de felicidade pessoal, a que o doutor Tomás Judym renunciou propositadamente.

O objetivo que norteia a ação do doutor Tomás Judym é grande e nobre. 0 altruísmo do médico guia-o na consagração cabal à

\footnotetext{
16 Passamos a citar a cena final, imbuída de profunda simbologia existencialista e positivista, centrada em torno do pinheiro dilacerado entre o dever e o amor: «Tuż obok stóp Judyma było szerokie, suche zwalisko. Otwór w postaci leja zwróconego wierzchołkiem na dół. W głębi ziemi pod nim były niegdyś galerie kopalni [...]. Gleba zewnętrzna zsunęta się w przepaść wraz z murawą, krzewami i utworzyła dót głębokości dwudziestu metrów. W miejscu rozdarcia widać było pręgi piachu siwe i jasnożółte. Naokół stały karłowate, nędzne sosny. Jedna z nich rosła na samym brzegu zwaliska. Oberwana ziemia ściągnęła w głębinę jej prawy korzeń, lewy został na twardym gruncie [...] Wszczepione w glebę pazury górne trzymały się z całej siły. Judym zsunął się w zwalisko, żeby go nikt nie widział. Rzucił się na wznak. [...] Tuż nad jego głową stała sosna rozdarta [...]. Słyszał dokoła siebie płacz samotny, jedyny, płacz przed obliczem Boga. Nie wiedział tylko, kto płacze ... Czy Joasia? - Czy grobowe lochy kopalni płaczą? Czy sosna rozdarta?» (Żeromski, 2016: 234-235). Assim acaba o romance Ludzie bezdomni, escrito em Zakopane, no outono de 1899.
} 
causa da melhoria das condições de vida da sociedade através do exercício da Medicina. A atitude e as reformas do protagonista de Żeromski permitem-nos defini-lo em termos de um novo Prometeu, tardo-romântico e positivista, envolvido nas engrenagens da propaganda comunista (anticonsumpcionista e convencida da solidariedade da classe da intelligentsia com o proletariado) no excelente filme intitulado Doktor Judym (O doutor Judym), com Jan Englert interpretando o doutor Tomás e Anna Nehrebecka no papel de Joanna Podborska. Trata-se de um filme polaco realizado por Jerzy Haupe e Andrzej Szczypiorski em 1975 e exibido com sucesso nos cinemas da Polónia ${ }^{17}$.

O doutor Tomás Judym é «um homem sem teto», um sem-abrigo, no significado explícito da palavra: é um médico-peregrino, sem local estável de habitação. É também um transeunte da classe social: operou a pas-

\footnotetext{
17 «Doktor Judym - polski film obyczajowy z 1975 roku na podstawie powieści Ludzie bezdomni Stefana Żeromskiego. Film jest opowieścią o życiu Tomasza Judyma, lekarza z powołania, który oprócz leczenia chorych pragnie usunąć też społeczne przyczyny chorób - nędzę i niesprawiedliwość społeczną, która tę nędzę wywołuje. Jego radykalizm i bezkompromisowość zraża do niego jednak środowisko ludzi bogatych. Judym w swoich poglądach i działaniach pozostaje samotny, tracąc także szansę na miłość w życiu prywatnym.» (Ludzie bezdomni..., 2013).

No romance, Stefan Żeromski recriou as suas vivências, observações, experiências pessoais e profissionais decorridas na Polónia e no estrangeiro (em Rappersville), retratando como protagonistas e deuteragonistas os seus amigos e colaboradores. 0 filme guarda esta faceta de uma película histórica e de costumes, com forte mensagem ideológica.
}

sagem do proletariado para a classe média, sem ser aceite por ela, sendo, na prática, rejeitado pelo meio dos médicos, ciosos e invejosos dos lucros financeiros ${ }^{18}$. 0 doutor Judym ficou só (abraçado, simbolicamente, ao pinheiro dilacerado, após ter rompido o namoro com Joanna Podborska) porque foi altruísta, um verdadeiro filantropo social na área da Medicina, um reformador espiritual e prático, um construtor da modernidade incómoda e ingrata, em que o individualismo nada tem que ver com a realização do seu próprio eu e com a perseguição das paixões e veleidades instantâneas, mas emprega-se para o bem-estar da comunidade, para «derrubar essas covas fétidas e não contemplar as flores campestres num vaso» porque pura e simplesmente não se pode assim fazer ${ }^{19}$.

\footnotetext{
${ }^{18}$ «Medycyna to interes jak każdy inny. Nie zapomnij kolega o tym... [Medicina é negócio como qualquer um. O colega não se esqueça disso...]» (Żeromski, 2016: 53).

${ }^{19}$ «Ja muszę rozwalić te śmierdzące nory. Nie będę patrzył, jak żyją i umierają ci od cynku. Polne kwiaty w doniczce, to tak ... To dobrze ... Ale czy można?» (Żeromski, 2016: 232).
} 


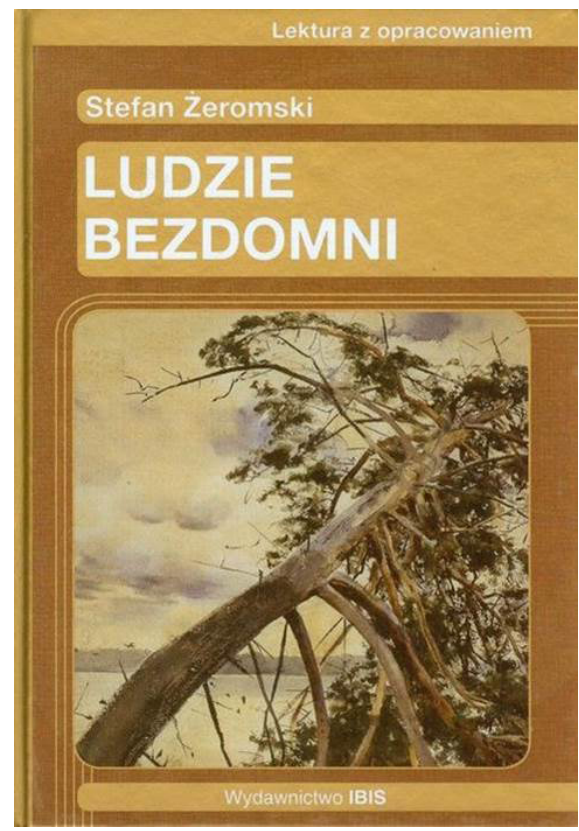

Foto 3 - Stefan Żeromski (2013). Ludzie bezdomni. Lektura z opracowaniem. Wyd. IBIS. Żychlin. Capa d'Os homens sem teto, ou o «pinheiro dilacerado», símbolo do doutor Tomás Judym. (Domínio público)

\section{Sousa Martins, um reformador} da Medicina para além dos limites da superstição científica, contra a tuberculose e em prol dos pobres

José Tomás de Sousa Martins (Vila Franca de Xira, Alhandra, 7 de março de 1843 - Vila Franca de Xira, Alhandra, 18 de agosto de 1897) era filho de Caetano Martins, carpinteiro, e de Maria das Dores de Sousa Martins, doméstica. Em Alhandra, completou o ensino primário. Ficou órfão de pai aos sete anos de idade.

Sousa Martins foi um médico afamado e professor catedrático da Escola Médico-Cirúrgica de Lisboa, antecessora da Faculdade de Medicina da Universidade de Lisboa. Foi um vulto incontornável da sociedade do século XIX, um pioneiro e um reformador do ensino da Medicina. A memória de José Tomás de Sousa Martins perdura até hoje, sendo um dos mé- dicos mais prestigiados de Portugal, chamado «o pai dos pobres», empenhado no combate à tuberculose, advogado da Medicina em detrimento da ganância e da superstição. No nosso entender, o doutor Sousa Martins era a realização das ideias representadas pelo doutor Tomás Judym.

Foi a generosidade de Sousa Martins que o tornou, aos olhos do povo, num santo homem, próximo de Santo António e de Nossa Senhora da Fátima. ${ }^{20} \mathrm{O}$ doutor Sousa Martins empenhou-se em diversas missões científicas e publicou vários trabalhos, sendo de sublinhar o seu interesse pelas doenças contagiosas, não só do ponto de vista científico e clínico, mas também do ponto de vista da saúde pública e doutrinal. Foi o relator da terceira farmacopeia oficial portuguesa, obra marcante na História da Farmácia em Portugal. Mais, contribuiu para a formação de diferentes construções imaginárias em torno da sua figura, na charneira do seu inegável progressismo e dos seus dotes sobrenaturais, contribuindo tudo para o conceito da consciência comum da sociedade moderna portuguesa como um convicto seguidor do positivismo.

\footnotetext{
${ }^{20}$ Até hoje, José Tomás de Sousa Martins é considerado uma pessoa santa, a quem se pode dirigir uma oração, vide Maria Helena (s. d.).
} 


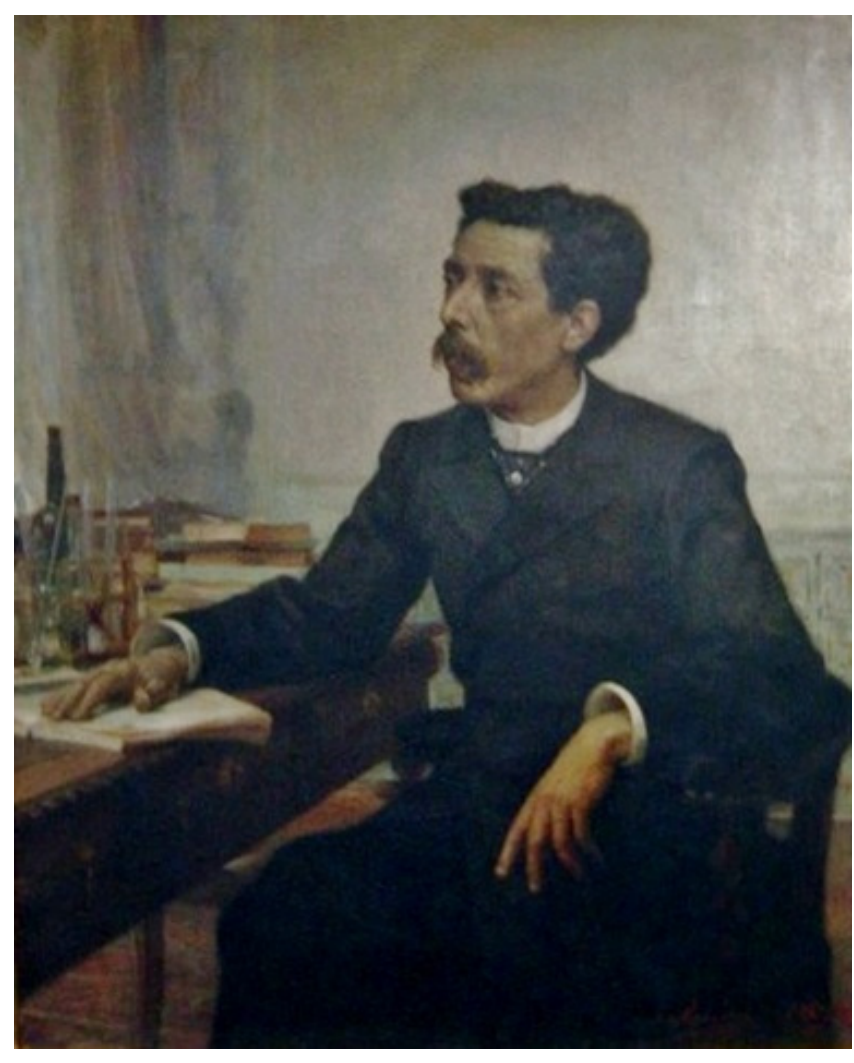

Foto 4 - José Tomás de Sousa Martins (1843-1897). Retrato na Sociedade de Ciências Médicas de Lisboa (1899). Pintor desconhecido. (Domínio público)

José Tomás de Sousa Martins é uma figura ímpar da Ciência portuguesa e um dos vultos incontornáveis das Ciências da Saúde e da clínica médica em Portugal, na segunda metade do século XIX.Aos 12 anos de idade, foi aconseLhado pela mãe a partir para Lisboa, onde um tio materno, Lázaro Joaquim de Sousa Pereira, era proprietário da Farmácia Ultramarina, na Rua de São Paulo. Trabalhou como aprendiz na farmácia, frequentando ao mesmo tempo o Liceu Nacional de Lisboa. A 1 de abril de 1856, iniciou oficialmente funções como praticante de botica na Farmácia Ultramarina, gerida pelo irmão da sua mãe - «tio amantíssimo e desvelado protector» (Telles, 1904: 65). Ganhou experiência como manipulador de produtos naturais e adquiriu conhecimentos que depois muito valorizou como médico e professor de Medicina. Desde 8 de julho de 1903, a sua memória é perpetuada na Rua Sousa Martins.

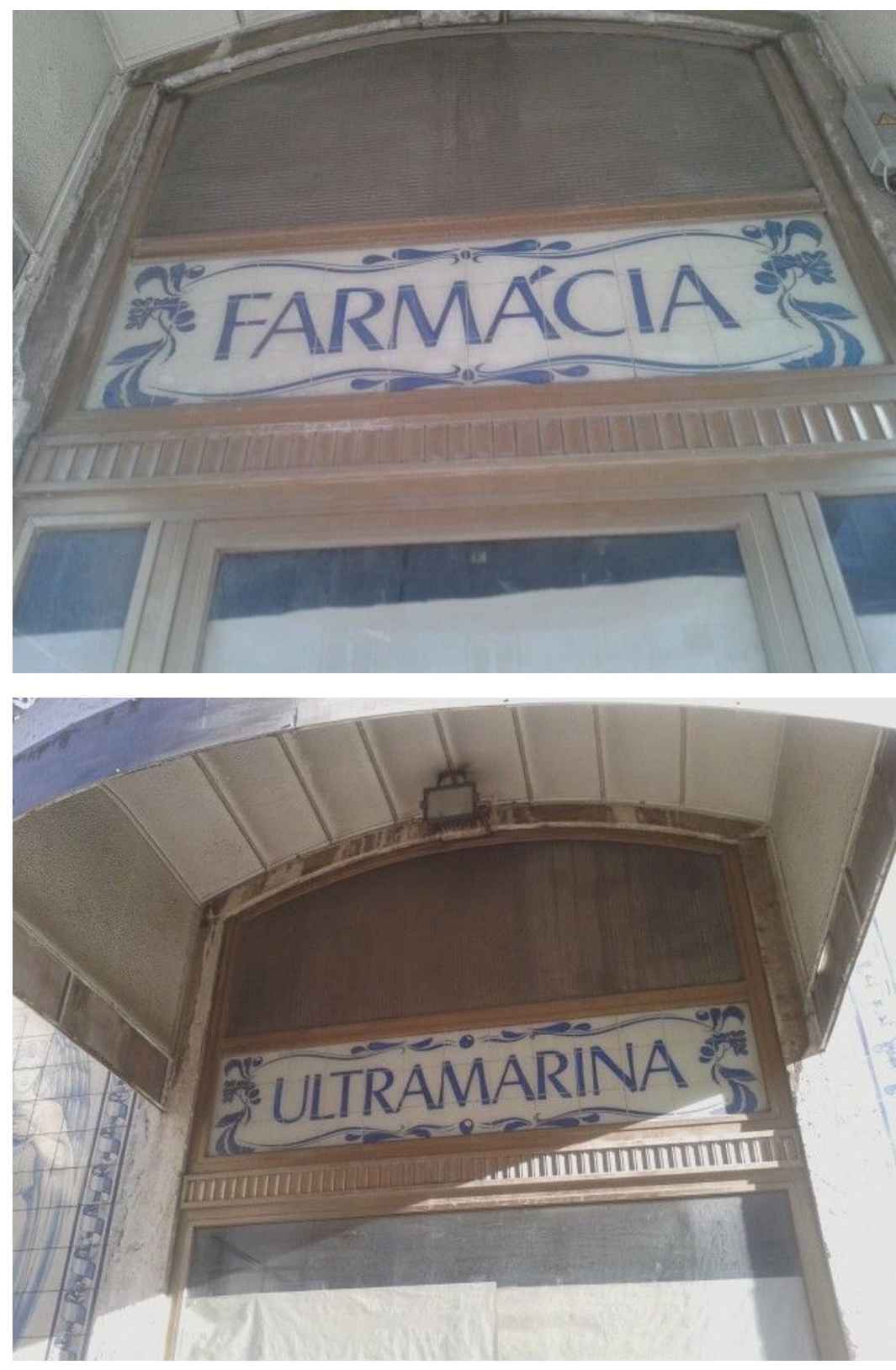

Foto 5 e foto 6 - Farmácia Ultramarina. Rua São Paulo 99, freguesia da Misericórdia, concelho e distrito de Lisboa. (Fot. de Anna Kalewska, 20 de maio de 2017)

A Farmácia Ultramarina, onde José Tomás de Sousa Martins trabalhou afincadamente como aprendiz e praticante nas horas livres dos cursos liceal e superior, estava encerrada 
quando a visitamos a 20 de maio de 2017. Conservaram-se, porém, em dois painéis de azulejos, o Anjo Custódio e a ficha da direção técnica e de análises clínicas, respetivamente, do lado esquerdo e direito da entrada.
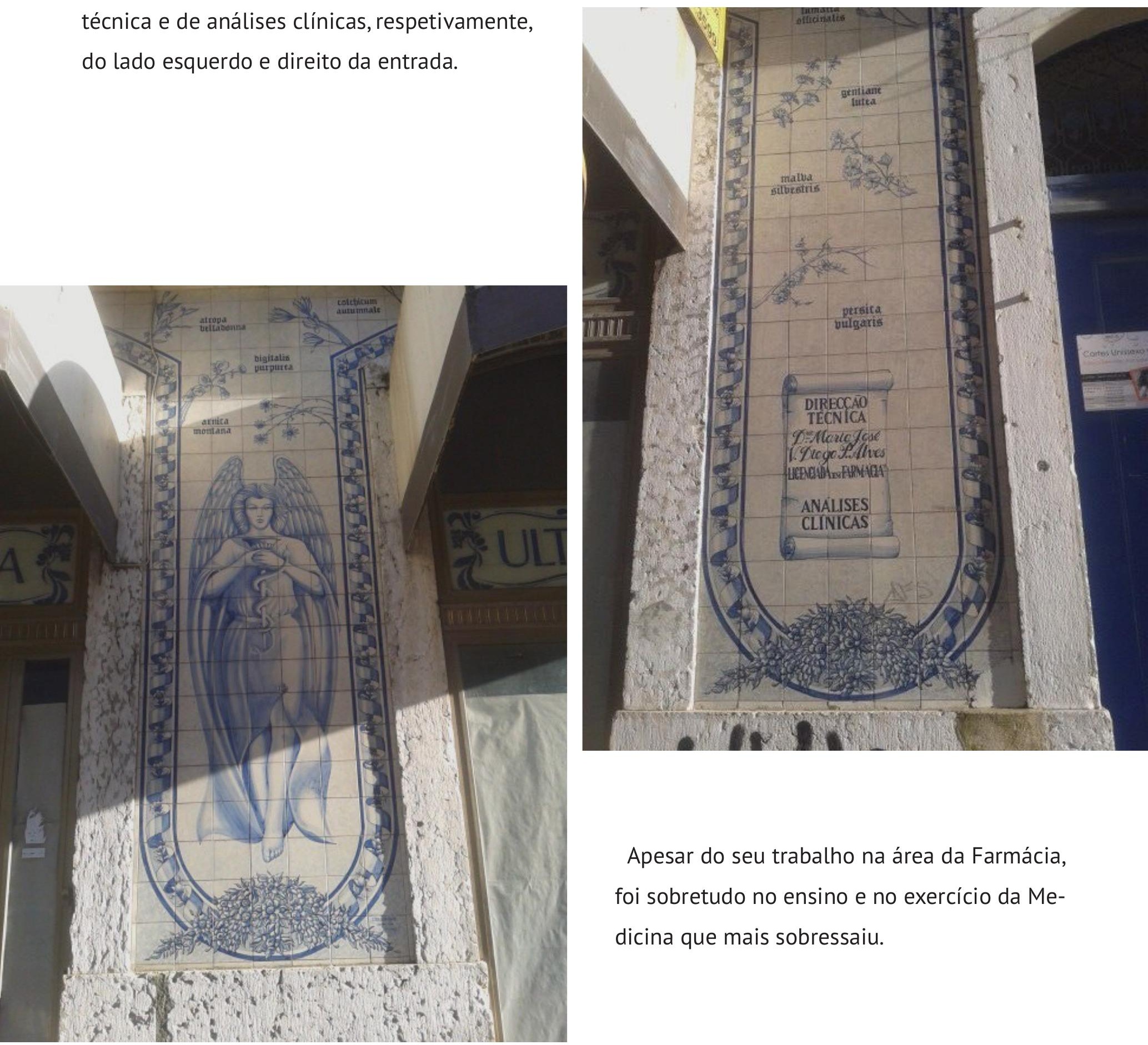

Foto 7 e foto 8 - Os dois painéis de azulejos ladeando a entrada da Farmácia Ultramarina em Lisboa: o Anjo Custódio (à esquerda) e a ficha técnica da direção e das análises clínicas (à direita). (Foto de Anna Kalewska, 20 de maio de 2017) 

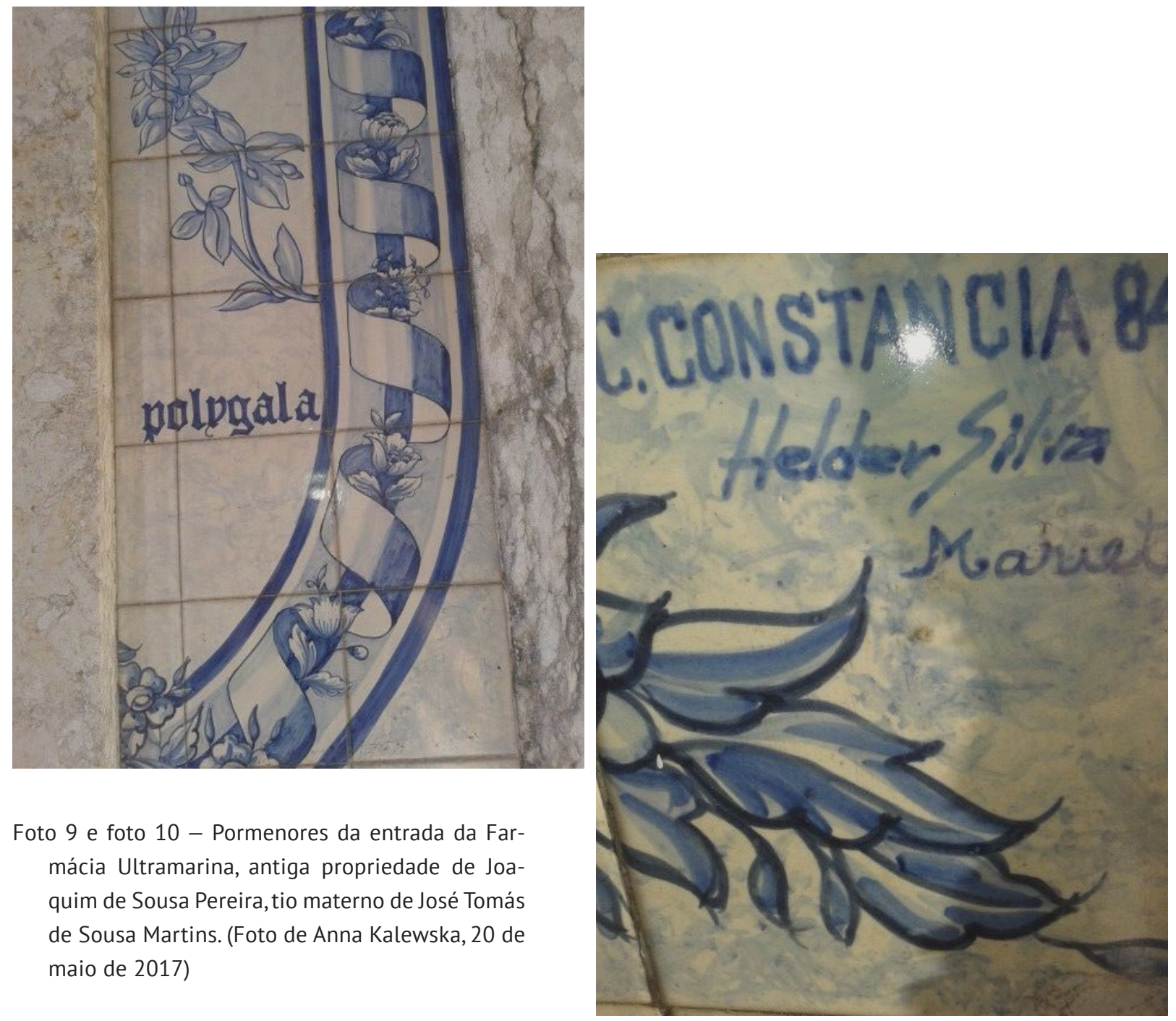

Em 1864, Sousa Martins concluiu o curso de Farmácia, aos 21 anos de idade, com excelente classificação. Dois anos depois, em 1866, terminou a licenciatura em Medicina na Escola Médico-Cirúrgica de Lisboa, apresentando uma dissertação intitulada Pneumogástrico preside à tonicidade da fibra muscular do coração. Sousa Martins redigiu ainda vários artigos, em cooperação com periódicos da época. Colaborou com a Gazeta Médica de Lisboa, o Jornal da Sociedade Farmacêutica Lusitana, o Jornal da Sociedade das Ciências Médicas de Lisboa, A Revista Médica Portuguesa, a Revista Ocidental, a
Medicina Contemporânea, o Diário Ilustrado e a Enciclopédia Popular.

Em 13 de julho de 1864, José Tomás de Sousa Martins foi eleito sócio efetivo da Sociedade Farmacêutica Lusitana, por proposta de José Tedeschi (1816-1904) - farmacêutico, professor de Farmácia e fundador do Partido Socialista Português -, publicando vários artigos no Jornal da Sociedade Farmacêutica e desempenhando também um papel relevante na regulação de diversas práticas potencialmente perigosas para a saúde pública. Nisso tem no doutor Judym o seu gémeo espiritual, 
mais uma razão para ser considerado o grande representante do espírito das reformas sociais em Portugal.

Em 1867, Sousa Martins foi eleito sócio correspondente da Academia Real das Ciências de Lisboa. Concluído o curso médico, no decorrer do qual foi um aluno brilhante, em 1868, foi nomeado, após concurso público, para o cargo de docente e investigador da secção médica da Escola Médico-Cirúrgica de Lisboa. Nesse mesmo ano, foi eleito sócio da Sociedade das Ciências Médicas de Lisboa, iniciando uma carreira ligada ao ensino e à investigação na área da Medicina. Em 1872, foi nomeado lente da Escola Médico-Cirúrgica de Lisboa e, em 1874, médico extraordinário do Hospital de São José. A lista cabal dos títulos honoríficos outorgados ao doutor Sousa Martins (inclusive o de académico correspondente da Real Academia de Medicina e Cirurgia de Madrid, em 1895) é apresentada por Sara Repolho (2008). Em 1883, foi promovido a médico ordinário do banco desse hospital e, em 1885, foi nomeado diretor de enfermaria - a «sua» enfermaria de São Miguel, que passou, depois da sua morte, a designar-se enfermaria Sousa Martins. É nesse contexto de enfermaria que Sousa Martins afirma a sua autoridade enquanto clínico, reformador, pasteuriano e positivista convicto. Ainda que pertencesse ao quadro do hospital, Sousa Martins criticou publicamente a sua administração, defendendo a competência e o supremo interesse do doente. A sua atividade académica no Hospital de São José e, em particular, a importante ação filantrópica que exercia a favor dos doentes mais pobres confirmaram-no como um dos médicos mais prestigiados de Portugal. Podemos dizer, à laia de primeira conclusão, que o doutor Sousa Martins realizou plenamente em Portugal aquilo que o doutor Tomás Judym tinha ideado na Polónia. «Encontramos em Sousa Martins o exercício da medicina como sacerdócio.A pedido da mãe [...] Sousa Martins manteve consulta gratuita para a população desfavorecida. A actividade clínica foi [...] marcada pela prática de caridade.» (Repolho, 2008: 41).

Sousa Martins desenvolveu uma importante ação filantrópica, que exercia a favor dos doentes mais pobres, como o «doutor Judym português» (segundo o nosso modesto entender). Ganhou enorme prestígio na luta contra a tuberculose, que então atingia proporções epidémicas em Lisboa. Bem nos explicita Sara Repolho:

\footnotetext{
Enquanto clínico, é de realçar o seu empenho e tratamento da tuberculose. Pugnou pela criação de sanatórios, considerando a serra da Estrela como localização privilegiada para a sua criação, devido ao clima de altitude. Frisou a necessidade de políticas sanitárias eficazes na prevenção das doenças. Morrera antes de concretizar o projecto de publicação de um estudo sociológico [com a descrição das doenças pulmonares e a sua etiologia]. (Repolho, 2008: 41)
}

É de lembrar que Sousa Martins foi reconhecido no estrangeiro, especialmente pelos brasileiros, que vinham a Portugal para recorrer à sua 
consulta. «Segundo Thomaz de Mello Breyner, habitualmente, os doentes que se deslocavam ao estrangeiro para consultar a opinião de reconhecidos médicos levavam consigo relatório elaborado por Sousa Martins, em língua francesa» (Repolho, 2008: 40).

Em 1888, Sousa Martins foi nomeado médico honorário da Real Câmara de Suas Majestades e Altezas e do Governo; em 1891, liderou a expedição científica à Serra da Estrela, defendendo a necessidade da construção de sanatórios destinados à climoterapia e considerando as Penhas Douradas como o lugar mais saudável em Portugal. Igualmente por iniciativa do doutor Sousa Martins, foi construído um pavilhão na Serra da Estrela, para internamento de tuberculosos, com 54 quartos, chamado Sanatório Sousa Martins ${ }^{21}$ - a construção foi realizada como o primeiro objetivo materializado após a sua morte.

Aos 54 anos de idade, em 18 de agosto de 1897, tuberculoso e sofrendo de uma lesão cardíaca, Sousa Martins teria cometido suicídio, com uma injeção de morfina. Ao morrer, fez uma confidência a um amigo: «A morte não é mais forte do que eu» e «Um médico ameaçado de morte por duas doenças, ambas fatais, deve eliminar-se por si mesmo». Sobre a sua morte, disse o rei

\footnotetext{
${ }^{21}$ O Sanatório das Penhas da Saúde/Sanatório da Covilhã/ Sanatório dos Ferroviários (antigo Sanatório Sousa Martins) tornou-se um estabelecimento de saúde pública na década de 1950 , sendo equipado com uma moderna sala de operações. Em 2014, foi convertido numa unidade hoteleira, a Pousada da Serra da Estrela.
}

D. Carlos I de Portugal: «Ao deixar o mundo, chorou-o [José Tomás de Sousa Martins] toda a terra que o conheceu. Foi uma perda irreparável, uma perda nacional, apagando-se com ele a maior luz do meu reino». António Egaz Moniz, Prémio Nobel da Medicina em 1949, achou-o «um nome aureolado e prelector admirável, de clínico, de orador consagrado». Segundo Guerra Junqueiro (1850-1923) - o escritor, jornalista e poeta, cuja poesia ajudou a criar o ambiente revolucionário que conduziu à Implantação da República portuguesa em 1910 - era «o amigo, carinhoso e dedicado dos pobres e dos poetas» (José Tomás ..., s. d.).

Sousa Martins viveu fascinado pela Ciência e pelo conhecimento certo e racional da natureza das coisas e das suas condições de existência no seu tempo. Manuel Bento de Sousa (1835-1899), um médico português, recolhido e educado pelos condes de Murça, presidente da Sociedade das Ciências Médicas de Lisboa (1875-1876), caracterizou-o, em 1904, como «um fiel, um devoto, um crente disciplinado» na Ciência, «em que tudo se lhe submetia» (Repolho, 2008: 11). Em 1910, Jaime Cortesão (1884-1960), um médico, político, escritor e historiador português, traçou o perfil de Sousa Martins, sublinhando que «em filosofia foi positivista, materialista e determinista-fatalista, tudo aquilo a que a superstição leva os que prezam a ciência para além dos limites do razoável» (Repolho, 2008: 11). O seu interesse e a sua paixão pela Ciência, pelas reformas e pela racionalidade foram focados por muitos autores seus contemporâneos. 
Um dos traços do perfil científico de Sousa Martins foi a sua paixão por Louis Pasteur (1822-1895), um cientista francês, fundador da teoria microbiológica da Ciência. Sara Repolho (2008) frisou esta paixão, uma das características do médico que também nos é mais cara. Na verdade, Sousa Martins era um pasteuriano convicto e partilhou as ideias científicas do mestre francês. «Para Sousa Martins, Pasteur era um dos santos a adorar na sua vasta religião da ciência» (Repolho, 2008: 11). A 12 de outubro de 1895, Sousa Martins fez um discurso na Sociedade das Ciências Médicas, cujo tópico estava subordinado às comemorações de Louis Pasteur. Sara Repolho considerou este discurso «uma verdadeira profissão da fé» (2008: 37). 0 doutor Tomás Judym dizia também que Pasteur era um nome que a memória dos homens nunca esqueceria. Eis a confissão da fé, o credo e o ponto de partida das ideias apregoadas por dois «sonhadores práticos». Para ambos, Pasteur era um dos mestres a adorar na vasta religião da Ciência.

\section{0 culto do médico «santo laico» entre a fé e a razão}

Vejamos o monumento realizado pelo escultor Queiroz Teixeira e inaugurado a 7 de março de 1900, data da comemoração do nascimento de Sousa Martins:

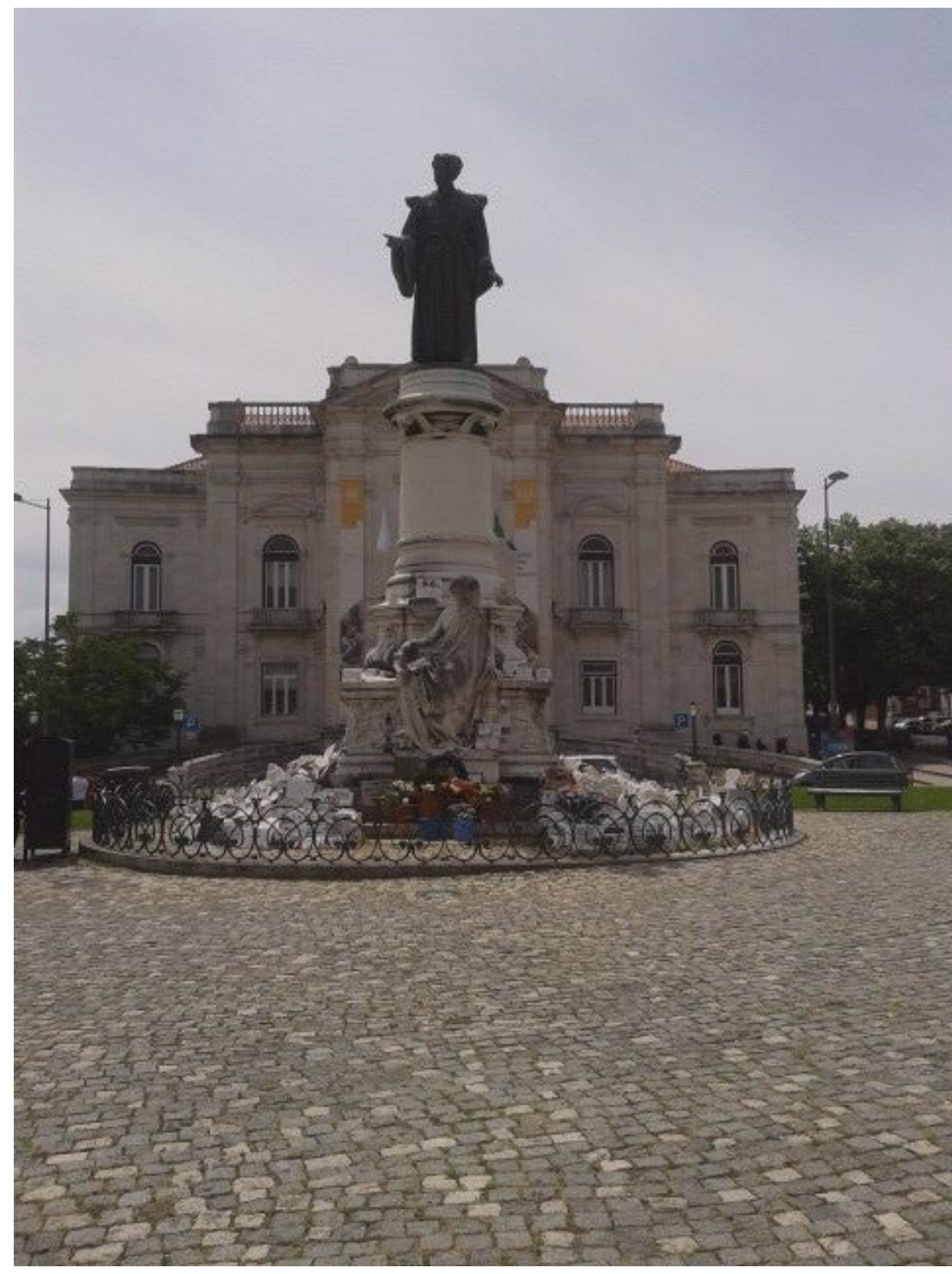

Foto 11 - A estátua de José Tomás de Sousa Martins no Campo dos Mártires da Pátria, junto à Faculdade de Ciências Médicas de Lisboa. (Foto de Anna Kalewska, 20 de maio de 2017)

Em 1904, esse monumento foi substituído por outro, da autoria de Costa Mota, sendo inaugurado precisamente quatro anos depois, numa nova comemoração do nascimento de Sousa Martins. É esta a estátua que presentemente se pode observar no Campo dos Mártires da Pátria, em frente à Faculdade de Ciências Médicas.

É em torno deste monumento que muitas pessoas prestam culto a Sousa Martins. São inúmeras as placas de mármore e as ofertas dos devotos, reconhecidos pelas graças obtidas e 
pelos desejos concretizados pela intervenção do santo. Aí acorrem centenas de pessoas, nas datas de comemoração do nascimento e falecimento de Sousa Martins e no dia de finados. Há sempre, no entanto, ao longo de todo o ano, devotos que rezam, que oferecem flores e acendem velas. A par dos devotos, surgem os vendedores de flores, velas e artigos místicos diversos alusivos a Sousa Martins. Relativamente à natureza da «intercessão» de Sousa Martins, explica Sara Repolho:

Os crentes recorrem a Sousa Martins em busca de graças e milagres. Poder-se-iam entender as «graças» como os benefícios concedidos pelo santo em favor da pessoa que a ele recorre. No fundo, é a concretização do desejo formulado pelo crente e pedido ao santo. Os milagres assumiriam já uma intervenção difícil de explicar através do actual conhecimento humano. [...] É comum o recurso a Sousa Martins, quando há necessidade de uma intervenção cirúrgica. 0 seu papel será o de garantir que tudo correrá bem. Há, no entanto, relatos da sua miraculosa intervenção, levando a que não houvesse já a necessidade de operação. Uma senhora afirmou que o marido iria ser sujeito a intervenção cirúrgica à garganta. Esposa pediu intercessão de Sousa Martins. Quando fez os últimos exames para poder ser depois operado, os médicos constataram que a operação já tinha sido realizada. São também comuns relatos de pacientes que dizem ter sido assistidos por ele no hospital. Perante casos graves a nível de saúde (cancro, perda de visão, meningite, situações de coma, doenças raras, problemas cardíacos, AVC's, complicações de saúde ainda não diagnosti- cadas...), os crentes pedem ou a intervenção directa de Sousa Martins sobre o doente ou pedem-lhe que «ilumine» os médicos. A eficácia da cura resulta, então, das práticas da Medicina convencional sob influência/orientação divina. São citados casos de desaparecimento de dor após feridas graves, e casos de depressão que, com o auxílio e amparo de Sousa Martins, são ultrapassados. Mas como é que ele ampara? Os crentes dizem sentir a sua presença por perto. É frequente o recurso à expressão «falar com ele». Sousa Martins é apresentado como uma entidade que interage, comunica, dialoga. Muitos devotos afirmam ouvi-lo. Escutam os seus conselhos. Sousa Martins «compreende» os problemas e sentimentos dos devotos e «faz-se compreender». As graças recebidas não se prendem apenas com casos de saúde. Muitas pessoas recorrem ao santo quando têm problemas com os filhos (ex.: filha «desencaminhada», problemas escolares). Há casos em que as mulheres, através da devoção por Sousa Martins e seu amparo, ganham coragem para deixar os maridos que as maltratam. [...] Sousa Martins auxilia na própria mudança de atitude face à vida. Faz entender melhor a vida, com mais amizade, mais alegria, mais amor, com bons conselhos. [...] Nem sempre há, portanto, uma relação temporal lógica na atribuição da intervenção de Sousa Martins. (Repolho, 2008: 65-66)

Os devotos sabem bem que Sousa Martins não é santo aos olhos da Igreja. Sabem, mas isso não é relevante para a sua devoção. Sentem-se bem quando «falam» com ele, acreditam que as suas preces são atendidas. As pessoas, acreditando na cura, podem ultrapassar algumas 
doenças. É positiva a crença em Sousa Martins, se servir de instrumento para a melhoria da saúde. Este médico «santo laico», a par de Santo António, de Nossa Senhora de Fátima, das santificadas crianças de Fátima (2017) e de outras tantas santidades/ entidades/divindades, cabe na religiosidade popular em Portugal e nas características tradicionais do povo português diagnosticadas por Jorge Dias (Real, 2017):

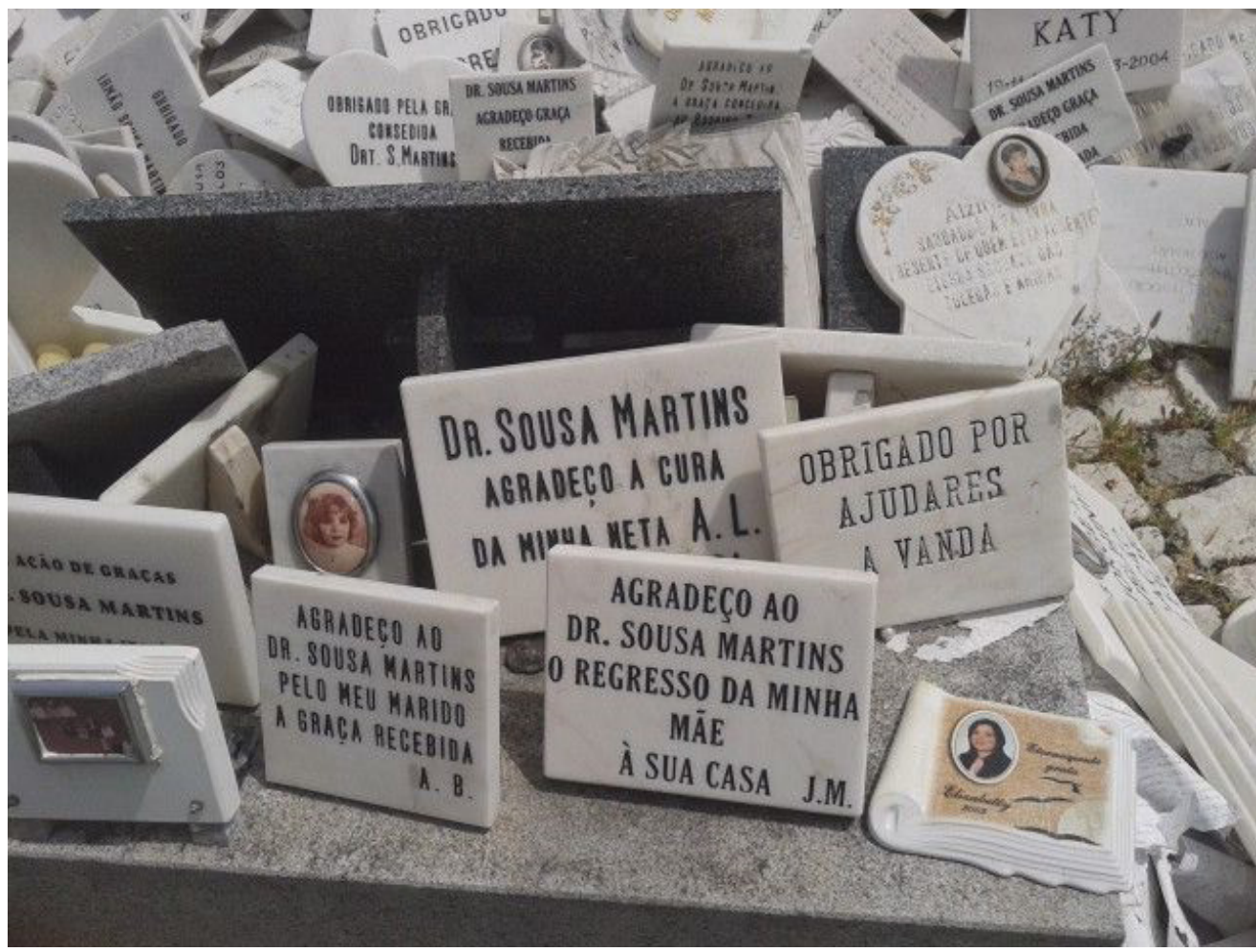

a religiosidade sentimental,

amorosa, bondosa, a sacrali-

zação da natureza e a aversão à racionalidade científica e filosófica ${ }^{22}$. 0 que não deixa de ser curioso, considerando o facto de Sousa Martins estar perfeitamente enraizado na doutrina positivista da sua época.

22 Por via de uma interpretação culturológica muito sui generis, identificávamos no culto de Sousa Martins o quarto mitologema diagnosticado por Gilbert Durand (1997), referindo-se às características do imaginário profundo do povo português: o mitologema ou a discursiva sequência lendária da transubstanciação, da transformação milagrosa da água em vinho ou do pão dos pobres em rosas, ou o «complexo de Canaã».
Foto 12 - As lápides de agradecimento junto à estátua de José Tomás de Sousa Martins. (Foto de Anna Kalewska, 20 de maio de 2017).

José Machado Pais avança uma explicação sociológica e antropológica para o fenómeno de José Tomás de Sousa Martins em termos da troca de causa e efeito:

As circunstâncias favorecedoras ou factores propiciativos das crenças não devem, contudo, ser confundidos com as causas das crenças. As explicações profanas ou comuns confundem quase sempre as simples condições ou circunstâncias do surgimento de um fenómeno com as causas efectivas desse fenómeno. Por exemplo, a causa do fogo é a presença de oxigénio. [...] Também as explicações profanas do mito de Sousa Martins assentam em circunstâncias isoladas que rodearam a vida do médico e [...] algumas 
dessas circunstâncias estão na base de crenças diferentes. Assim, a afabilidade do médico para com os doentes mais pobres é causa (santo homem) - nas explicações profanas - das crenças «progressista» e no «fazedor de milagres» (homem santo). Ou seja, a atribuição causal dos dotes de Sousa Martins é feita através de conduta do médico: o carinho com que tratava os doentes mais pobres. É normal, nas explicações profanas, que se erijam como causas de um dado fenómeno circunstâncias que estão numa relação de vizinhança com esse fenómeno e que se destacam pela sua anormalidade ou pouca frequência. Estas circunstâncias, que fazem a diferença, podem ser qualificadas de «anormais». Ora, para os pobres a quem Sousa Martins consultava, não era «normal» serem tratados como o eram por uma pessoa tão distinta e ilustre. Deste modo, começaram a alimentar uma imagem ou representação do médico que acaba por se revelar uma crença. E, como todas as crenças são produtoras de uma realidade (a realidade da crença), assim surgiram as memórias reais de Sousa Martins [...]. Não é verdade que as causas, em princípio, precedem os efeitos? (Pais, 1994: 212)

Tomás Judym e Sousa Martins entraram, respetivamente, na Literatura polaca e na História da Saúde Pública em Portugal como «santos laicos», figuras paradigmáticas da ação no campo das reformas sociais, como médicos ao serviço do Homem que não viam na religião o caminho da sua salvação, mas antes na Ciência, na ação direta no combate contra a pobreza e a tuberculose, re- nunciando à felicidade pessoal. E, também por isso, as figuras dos dois «sonhadores práticos» se tornam ainda mais fascinantes e recomendadas à apresentação no tempo do debate sobre o espírito das reformas e a (re)construção da modernidade. «Afinal, sentimos, no íntimo de nós, a Europa como lugar de múltiplas diferenças, que trazem consigo a audácia da liberdade» (Martins, 2012: 229).

Foi longo o caminho da génese do espírito das reformas. A herança e o legado da História no domínio dos Estudos Culturais, da História das Ideias e das personagens ilustres de reformadores - racionalistas e ficcionais, «santos laicos» e entidades fundadoras de crenças, convicções, ideias e sistemas filosóficos - são bem marcantes na continuidade do processo de modernidade (re)construída através de várias correntes de pensamento, opinião e ação tendentes a dar forma a um velho sonho, a uma utopia perene de amizade e cooperação entre a Polónia e Portugal, em virtude da meritória ação dos dois «sonhadores práticos» - o doutor Tomás Judym e o doutor José Tomás de Sousa Martins. 


\section{Bibliografia}

\section{Impressa}

Adamczewski, S. (1930). Serce nienasycone: Książka o Żeromskim. Wydawnictwo Polskie. Poznań;

Durand, G. (1997). Imagens e reflexos do imaginário português. Hugin. Lisboa;

Hutnikiewicz, A. (1960). Stefan Żeromski. Wiedza Powszechna. Warszawa;

Jabłońska, K. (1967). Oktawia. Wydawnictwo Lubelskie. Lublin;

Kądziela, J. (1976). Młodość Stefana Żeromskiego. Państwowy Instytut Wydawniczy. Warszawa;

Martins, G.O. (2012). Posfácio. Ideias de Europa e Portugal... Em: J.E. Franco e P. Calafate (coords.), A Europa segundo Portugal. Ideias de Europa na cultura portuguesa, século a século. Gradiva. Lisboa;

Milosz, C. (1984). The History of Polish Literature. (2. ${ }^{a}$ ed.). University of California Press. Berkeley-Los Angeles-London;

Pais, J.M. (1994). Sousa Martins e suas memórias sociais. Sociologia de uma crença popular. Gradiva. Lisboa;

Real, M. (2017). Traços fundamentais da cultura portuguesa. Planeta. Lisboa;

Repolho, S. (2008). Sousa Martins. Ciência e espiritualismo. Imprensa da Universidade de Coimbra. Coimbra;

Siewierski, H. (2000). História da Literatura polonesa. Universidade de Brasília. Brasília;

Telles, J.J.S. (1904). Sousa Martins: In memoriam. Officina Typographica da Casa Moeda. Lisboa;

Zamoyski, A. (2010). História da Polónia. (Trad. M. Mata). Ediç̧ões 70. Lisboa;

Żeromska, M. (2007). Wspomnień ciąg dalszy. Czytelnik. Warszawa;

Żeromski, S. (2016). Ludzie bezdomni. Wyd. III poprawione, oprac. A. Popławska, H. Liszka. Wydawnictwo GREG. Kraków.

\section{Digital}

Câmara Municipal de Lisboa (2013, 7 de março). A Rua Sousa Martins no seu $1700^{\circ}$ aniversário. Toponímia de Lisboa. Acedido em 20 de julho de 2017, em: https://toponimialisboa.wordpress.com/2013/03/07/953/;

Ceia, C. (s. d.). Estudos culturais. E-dicionário de termos literários. Acedido em 20 de julho de 2017, em: http://edtl.fcsh.unl.pt/business-directory/6910/estudos-culturais/;

Jesus, C. (s. d.). Sousa Martins, o santo que não acreditava em Deus. Selecções Reader's Digest. Acedido em 24 de julho de 2017, em: http://www.seleccoes.pt/1/sousa_martins_o_santo_que_nao_acreditava_em_ deus_2281383.html;

José Tomás de Sousa Martins (s. d.). Acedido em 24 de julho de 2017, em: https://pt.wikipedia.org/wiki/Jos\%C3\%A9_Tom\%C3\%A1s_ de_Sousa_Martins;

Ludzie bezdomni (Doktor Tomasz Judym 1975) Stefan Żeromski (2013, 2 de agosto). Acedido em 22 de novembro de 2018, em: https:// www.youtube.com/watch?v=Q__EbFrKkFo;

Maria Helena (s. d.). Oração ao Dr. Sousa Martins. Maria Helena. Acedido em 24 de julho de 2017, em: http://www.mariahelena. pt/pages/oracao-ao-dr-sousa-martins;

Nałęczów, W kręgu Żeromskich. Acedido em 20 de julho de 2017, em: http://www.naleczow.com.pl/turystyka/turystyka.php?id=../ gazeta/2005/42/art/21\&pr=indeks_p;

Wąsacz, M. (2014, 3 de abril). Stefan Żeromski - Życie i twórczość. Bibliografia przedmioo towa. Pedagogiczna Biblioteka Wojewódzka $w$ Przemyślu. Acedido em 21 de novembro de 2018, em: https://przemysl.pbw.org.pl/ zestawienia-bibliograficzne-4,115/stefan-eromski-ycie-i-tworczo-bibliografia-przedmiotowa,9250;

Żukowska,E.(2012,25 de abril).Upiór Żeromskiego i duch Oktawii. Tekstologia. Acedido em 21 de novembro de 2018, em: https:// tekstologia.wordpress.com/2012/04/25/ upior-zeromskiego-i-duch-oktawii/. 